UNITED STATES ATOMIC ENERGY COMMISSION

DEVELOPMENT OF ZIRCONIUM ALLOYS. PART II

By

A. D. Schwope

W. Chubb

January 2, 1952

Battelle Memorial Institute Columbus, Ohio

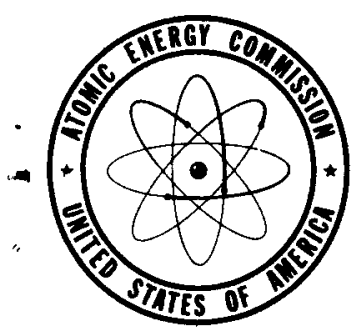

Technical Information Service, Oak Ridge, Tennessee 


\section{DISCLAIMER}

This report was prepared as an account of work sponsored by an agency of the United States Government. Neither the United States Government nor any agency Thereof, nor any of their employees, makes any warranty, express or implied, or assumes any legal liability or responsibility for the accuracy, completeness, or usefulness of any information, apparatus, product, or process disclosed, or represents that its use would not infringe privately owned rights. Reference herein to any specific commercial product, process, or service by trade name, trademark, manufacturer, or otherwise does not necessarily constitute or imply its endorsement, recommendation, or favoring by the United States Government or any agency thereof. The views and opinions of authors expressed herein do not necessarily state or reflect those of the United States Government or any agency thereof. 


\section{DISCLAIMER}

Portions of this document may be illegible in electronic image products. Images are produced from the best available original document. 


\section{2}

Date Declassified: November 9, 1955.

This report was prepared as a scientific account of Government-sponsored work. Neither the United States, nor the Commission, nor any person acting on behalf of the Commission makes any warranty or representation, express or implied, with respect to the accuracy, completeness, or usefulness of the information contained in this report, or that the use of any information, apparatus, method, or process disclosed in this report may not infringe privatelyowned rights. The Commission assumes no liability with respect to the use of, or from damages resulting from the use of, any information, apparatus, method, or process disclosed in this report.

This report has been reproduced directly from the best available copy.

Issuance of this document does not constitute authority for declassification of classified material of the same or similar content and title by the same authors.

Since nontechnical and nonessential prefatory material has been deleted, the first page of the report is page 7 .

Printed in USA, Price 20 cents. Available from the Office of Technical Services, Department of Commerce, Washington $25, \mathrm{D}$. C. 
$x$

$n$

1

$\checkmark$ 


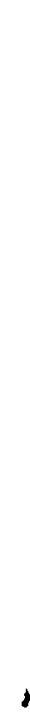




\title{
DEVELOPMENT OF ZIRCONIUM ALLOYS
}

PAR T II

\author{
Prepared by: A. D. Schwope \\ W. Chubb
}

January 2, 1952

\section{ABSTRACT}

A number of alloys of zirconium have been investigated as part of a program aimed at improving the high-temperature tensile and creep strength of zirconium. These alloys include aluminum, beryllium, lead, magnesium, molybdenum, niobium, tantalum, tin, titanium, tungsten, vanadium, and zinc, binary and ternary alloys.

The data indicate that aluminum, lead, molybdenum niobium, tin, titanium, tungsten, and vanadium can be used successfully to harden zirconium, and that aluminum, tin, titanium, and vanadium are particularly effective in maintaining the strength of zirconium at elevated temperatures.

BATTELLE MEMORIAL INSTITUTE

505 King Avenue

Columbus 1, Ohio 
EXPERIMENTAL WORK . . . . . . . . . . . . . . . 9

Fabrication of the Alloys . . . . . . . . . . . 99

Tensile Testing . . . . . . . . . . . . . . 13

Microstructure .. . . . . . . . . . . . 20

Corrosion Data . . . . . . . . . . . . . . 20

Transformation Temperatures . . . . . . . . . . 21

Heat-Treating Data... . . . . . . . . . . . 22

Hot-Hardness Data............... 23

CONCLUSIONS . . . . . . . . . . . . . . . . . 24 


\section{INTRODUCTION}

As part of a program on the development of zirconium and zirconium alloys for nuclear-reactor applications, a search has been made for alloys having good high-temperature strength. Such alloys should have high creep resistance and low neutron-absorption characteristics. On the assumption that these alloys might be used as structural members in place of stainless steel, Type 347, any such alloy should be as strong as stainless steel and

- have a lower neutron-capture cross section.

The early phases of this work were reported in BMI-79, and this report represents a continuation of the effort to find good high-temperature alloys of zirconium. The alloys investigated represent continued interest in some of the alloy systems reported in BMI-79, in addition to exploratory work in new systems.

Acceptable alloys should show a total creep of much less than one per cent in 10,000 hours at a stress of 10,000 psi at a temperature of $500 \mathrm{C}$; the alloys must have sufficient hot workability to enable them to be fabricated into simple shapes; and the alloys must have a neutron-capture cross section much less than that of stainless steel and equivalent strength.

As mentioned in BMI-79, in order to select alloys to be tested in creep, it was decided to evaluate the alloys by means of tensile tests at $500 \mathrm{C}$. To be acceptable for creep testing, it was decided that the alloys must have yield strengths at $500 \mathrm{C}$ approximately equal to that of stainless steel, Type 347, and neutron cross sections less than one-third that of stainless steel.

\section{EXPERIMENTAL WORK}

Fabrication of the Alloys

The zirconium used in this program was Foote Mineral Company iodide zirconium. Not all of this zirconium was of the highly corrosionresistant grade, since corrosion resistance was of minor interest in this program. The alloying elements used were of high purity.

The alloys were prepared in nonoutgassed graphite crucibles in an absolute pressure of less than ten microns of mercury, with the exception 
of the lead, zinc, and magnesium alloys. These alloys were prepared in an atmosphere of purified argon. About half of the materials were charged directly into the graphite crucibles. The crucibles were heated by highfrequency induction. When the crucible charge became molten, the remainder of the charge was dropped into the melt from a storage chamber. After the entire charge was molten, the melt was cooled slowly to reduce the depth of the shrinkage pipe.

In most cases, the minor alloying elements were placed in holes drilled in the zirconium pieces and sealed in with zirconium chips. The weight of materials charged was about $200 \mathrm{grams}$ and the resulting ingots usually weighed 160 to 180 grams. The analyses obtained from these ingots are shown in Table 1. It is apparent that zirconium-magnesium alloys cannot be prepared by induction melting at normal pressures. Considerable loss of zinc was experienced in the preparation of the zirconiumzinc alloy, and it is probable that 0.4 per cent zinc represents approximately the maximum amount that can be alloyed with zirconium by induction melting at atmospheric pressure.

The as-cast alloys were upset forged and hot rolled at $1000 \mathrm{C}$ to slabs $1 / 8$ inch thick. Approximately 0.010 inch was shaved from each side of the hot-rolled slabs to remove gaseous contaminants. The scalped slabs were cold rolled 20 to 30 per cent in reductions of approximately 0.002 inch per pass. The cold-rolled alloys were annealed in a straightening press for three hours at $700 \mathrm{C}$. The resulting sheet was scalped 0.010 inch on each side and cut into tensile specimens. Hardness data obtained during the fabrication of these alloys are shown in Table 2.

The 0.1 per cent beryllium alloy was oxidized and slivered beyond recovery during hot rolling. The 5.4 per cent molybdenum alloy and the 8.5 per cent tin alloy were cracked beyond recovery during hot rolling. The 3.1 per cent molybdenum ternary alloy, the 2.2 per cent columbium alloy, the 2.6 per cent aluminum ternary alloy, and the 3.4 per cent vanadium ternary alloy were cracked slightly during hot rolling. The 2. 6 per cent aluminum ternary alloy, the 3.4 per cent vanadium ternary alloy, the 3.7 per cent titanium ternary alloy, and the 2.5 per cent tantalum ternary alloy were shattered beyond recovery during cold rolling. Otherwis'e, the alloys forged and rolled without difficulty. It should be noted that the 3 . 1 per cent vanadium alloy showed considerably more resistance to oxidation at the hot-rolling temperature than most of the other alloys. 
TABLE 1. CHEMICAL ANALYSES FOR THE SECOND AND THIRD SETS OF ZIRCONIUM ALLOYS

\begin{tabular}{ll}
\hline $\begin{array}{l}\text { Nominal Alloy } \\
\text { (as designed), } \\
\text { weight per cent }\end{array}$ & \multicolumn{1}{c}{$\begin{array}{c}\text { Actual Alloy } \\
\text { (as analyzed), } \\
\text { weight per cent }\end{array}$} \\
\hline $0.5 \mathrm{Be}$ & $0.1 \mathrm{Be}+0.27 \mathrm{C}$ \\
$5 \mathrm{Mo}+1 \mathrm{Nb}$ & $3.1 \mathrm{Mo}+0.4 \mathrm{Nb}+0.26 \mathrm{C}$ \\
$3 \mathrm{Nb}$ & $2.2 \mathrm{Nb}+0.30 \mathrm{C}$ \\
$3 \mathrm{Al}+2 \mathrm{~W}$ & $2.6 \mathrm{Al}+1.2 \mathrm{~W}+0.21 \mathrm{C}$ \\
$3 \mathrm{~V}+2 \mathrm{Al}$ & $3.4 \mathrm{~V}+1.4 \mathrm{Al}+0.24 \mathrm{C}$ \\
$4 \mathrm{Ti}+3 \mathrm{Nb}$ & $3.7 \mathrm{Ti}+2.2 \mathrm{Nb}+0.33 \mathrm{C}$ \\
$2 \mathrm{Mg}$ & $0.003 \mathrm{Mg}+0.19 \mathrm{C}$ \\
$5 \mathrm{Mg}$ & $0.003 \mathrm{Mg}+0.36 \mathrm{C}$ \\
$3 \mathrm{Ta}+2 \mathrm{Sn}$ & $2.5 \mathrm{Ta}+1.1 \mathrm{Sn}+0.34 \mathrm{C}$ \\
$4 \mathrm{Ti}+2 \mathrm{Sn}$ & $3.3 \mathrm{Ti}+0.68 \mathrm{Sn}+0.43 \mathrm{C}$ \\
$0.5 \mathrm{Al}$ & $0.38 \mathrm{Al}+0.24 \mathrm{C}$ \\
$1.0 \mathrm{Al}$ & $0.87 \mathrm{Al}+0.26 \mathrm{C}$ \\
$5 \mathrm{Mo}$ & $5.4 \mathrm{Mo}+0.18 \mathrm{C}$ \\
$8 \mathrm{Sn}$ & $8.5 \mathrm{Sn}+0.19 \mathrm{C}$ \\
$2 \mathrm{~W}$ & $0.44 \mathrm{~W}+0.20 \mathrm{C}$ \\
$3 \mathrm{~V}$ & $3.1 \mathrm{~V}+0.20 \mathrm{C}$ \\
$2 \mathrm{Zn}$ & $0.40 \mathrm{Zn}+0.45 \mathrm{C}$ \\
$5 \mathrm{~Pb}$ & $4.7 \mathrm{~Pb}+0.23 \mathrm{C}$ \\
$4 \mathrm{Sn}+0.5 \mathrm{Al}$ & $2.8 \mathrm{Sn}+0.46 \mathrm{Al}+0.36 \mathrm{C}$ \\
$4 \mathrm{Sn}+1.0 \mathrm{Ta}$ & $4.6 \mathrm{Sn}+0.66 \mathrm{Ta}+0.24 \mathrm{C}$ \\
$7 \mathrm{Ti}$ & $6.4 \mathrm{Ti}+0.39 \mathrm{C}$ \\
\hline
\end{tabular}


TABLE 2. HARDNESS DATA FOR THE SECOND AND THIRD SETS OF ALLOYS

\begin{tabular}{lccc}
\hline \hline $\begin{array}{c}\text { Zirconium Alloys, } \\
\text { weight percent } \\
\text { (As Analyzed*) }\end{array}$ & \multicolumn{3}{c}{ Rockwell A Hardness } \\
\cline { 2 - 4 } $0.1 \mathrm{Be}$ & 65 & Cold Rolled & Annealed \\
$3.1 \mathrm{Mo}+0.4 \mathrm{Nb}$ & 64 & 67 & - \\
$2.2 \mathrm{Nb}$ & 59 & 61 & 63 \\
$2.6 \mathrm{Al}+1.2 \mathrm{~W}$ & 68 & $* * *$ & 57 \\
$3.4 \mathrm{~V}+1.4 \mathrm{Al}$ & 73 & $* * *$ & - \\
$3.7 \mathrm{Ti}+2.2 \mathrm{Nb}$ & 68 & $* * *$ & - \\
$0.003 \mathrm{Mg}$ & 64 & 62 & - \\
$0.003 \mathrm{Mg}$ & 42 & 53 & 44 \\
$2.5 \mathrm{Ta}+1.1 \mathrm{Sn}$ & 72 & $* * *$ & - \\
$3.3 \mathrm{Ti}+0.68 \mathrm{Sn}$ & 54 & 60 & 56 \\
$0.38 \mathrm{Al}$ & 41 & 55 & 50 \\
$0.87 \mathrm{Al}$ & 42 & 59 & 57 \\
$5.4 \mathrm{Mo}$ & 68 & $* *$ & - \\
$8.5 \mathrm{Sn}$ & 56 & $* *$ & - \\
$0.44 \mathrm{~W}$ & 58 & 58 & 51 \\
$3.1 \mathrm{~V}$ & 52 & 64 & 56 \\
$0.40 \mathrm{Zn}$ & 42 & 53 & 46 \\
$4.7 \mathrm{~Pb}$ & 50 & 58 & 54 \\
$2.8 \mathrm{Sn}+0.46 \mathrm{Al}$ & 52 & 58 & 56 \\
$4.6 \mathrm{Sn}+0.66 \mathrm{Ta}$ & 45 & 58 & 55 \\
$6.4 \mathrm{Ti}$ & 51 & 64 & 59 \\
& & & \\
\hline \hline
\end{tabular}

* Carbon analyses are shown in Table 1.

** Destroyed in hot rolling.

**** Destroyed in cold rolling. 


\section{Tensile Testing}

The tensile specimens prepared for this work had a 1-1/2-inch reduced section, were $0.50 \mathrm{inch}$ wide in the reduced section, and were 0.040 or 0.050 inch thick. Specimens were taken parallel to the rolling direction. These specimens were tested at $500 \mathrm{C}$ in an argon atmosphere. The speed of travel of the head of the testing machine was 0.02 inch per minute. An extensometer with a l-inch gage length and an accuracy of plus or minus 0.0001 inch per inch was used to measure extensions. This extensometer was of the clip- on type utilizing SR-4 gages with slide bars extending out of the heated area around the specimen.

The data from these tensile tests are shown in Table 3. The truestress, true-strain curves for significant alloys are shown in Figures 1 , 2 , and 3. The strain-hardening exponent, " $n$ ", is the slope of the plastic stress-strain curves, some of which are shown in Figure 4. The constant " $B$ " is the true stress when the true strain is equal to unity. These are the coefficients of the empirical relation, $\sigma=\mathrm{B} \delta$, where $\sigma$ is the true stress and $\delta$ is the true strain.

The best binary alloys in this group are the 2.2 per cent niobium alloy, the 0.87 per cent aluminum alloy, the 3.1 per cent vanadium alloy, the 4.7 per cent lead alloy, and the 6.4 per cent titanium alloy. All the ternary alloys in this group are very strong alloys. However, the 3.1 per cent molybdenum plus niobium alloy is rather brittle, and the 4.6 per cent tin plus tantalum alloy is not appreciably stronger than a binary alloy containing this amount of tin. The 2.8 per cent tin plus aluminum alloy and the 3.3 per cent titanium plús tin alloy show considerable strength plus satisfactory ductility.

In order to select alloys for creep testing, the thermal-neutroncapture cross section of each alloy was calculated by the method shown in BMI-79. This figure was divided by the thermal-neutron-capture cross section of Type 347 stainless steel (approximately 2.86 barns per atom). The resulting figure is shown as the "cross-section ratio" in Table 4. The "yield-strength ratios" shown in Table 4 are the ratio of the 0.2 per cent offset yield strength of each alloy to that of Type 347 stainless steel $(31,000 \mathrm{psi})$. As indicated in the introduction, the cross-section ratio of an acceptable alloy must be less than 0.33 and the yield-strength ratio must be approximately equal to 1.00 .

Since these alloys were compounded such that their theoretical thermal-neutron-capture cross sections would not exceed 0.95 , it is not surprising that the cross-section ratios of all the alloys are less than 0.33 . 


$$
14
$$

TABLE 3. DATA FROM TENSILE TESTS

\begin{tabular}{|c|c|c|c|c|c|c|}
\hline \multirow[b]{2}{*}{$\begin{array}{c}\text { Zirconium Alloys, } \\
\text { weight per cent } \\
\text { (As Analyzed*) }\end{array}$} & \multicolumn{6}{|c|}{ Tensile Properties at $500 \mathrm{C}$} \\
\hline & $\begin{array}{c}0.2 \% \\
\text { Offset } \\
\text { Yield Strength, } \\
1000 \mathrm{psi}\end{array}$ & $\begin{array}{l}\text { Ultimate } \\
\text { Strength, } \\
1000 \text { psi }\end{array}$ & $\begin{array}{l}\text { Per Cent } \\
\text { Elongation } \\
\text { in } 1 \text { Inch }\end{array}$ & $\begin{array}{l}\text { Per Cent } \\
\text { Reduction } \\
\text { of Area }\end{array}$ & $\begin{array}{c}\text { Hardening } \\
\text { Exponent, } \\
\text { " } n \text { " }\end{array}$ & $\begin{array}{c}\text { B, } \\
1000 \text { psi }\end{array}$ \\
\hline 3. $1 \mathrm{Mo}+0.4 \mathrm{Nb}$ & 32 & 39 & 12 & 16 & 0.062 & 50 \\
\hline $2.2 \mathrm{Nb}$ & 35 & 43 & 9 & 15 & 0.077 & 69 \\
\hline $0.003 \mathrm{Mg}$ & 16 & 24 & 30 & 44 & 0.096 & 33 \\
\hline $0.003 \mathrm{Mg}^{\prime}$ & 9 & 15 & 71 & 63 & 0.14 & 23 \\
\hline $3.3 \mathrm{Ti}+0.68 \mathrm{Sn}$ & 24 & 44 & 22 & 28 & 0.16 & 69 \\
\hline $0.38 \mathrm{Al}$ & 18 & 30 & 31 & 34 & 0.17 & 48 \\
\hline $0.87 \mathrm{Al}$ & 25 & 38 & 30 & 37 & 0.15 & 60 \\
\hline $0.44 \mathrm{~W}$ & 17 & 22 & 47 & 65 & 0.06 & 28 \\
\hline $3.1 \mathrm{~V}$ & 27.7 & 34.6 & 40 & 60 & 0.07 & 44 \\
\hline $0.40 \mathrm{Zn}$ & 12 & 23 & 47 & 46 & 0.16 & 34 \\
\hline $4.7 \mathrm{~Pb}$ & 21 & 31 & 31 & 39 & 0.11 & 44 \\
\hline $2.8 \mathrm{Sn}+0.46 \mathrm{Al}$ & 29.4 & 42 & 22 & 32 & 0.13 & 61 \\
\hline $4.6 \mathrm{Sn}+0.66 \mathrm{Ta}$ & 25.7 & 40 & 28 & 33 & 0.15 & 61 \\
\hline $6.4 \mathrm{Ti}$ & 29.8 & 42.4 & 19 & 28 & 0.12 & 66 \\
\hline
\end{tabular}

* Carbon analyses are shown in Table 1. 


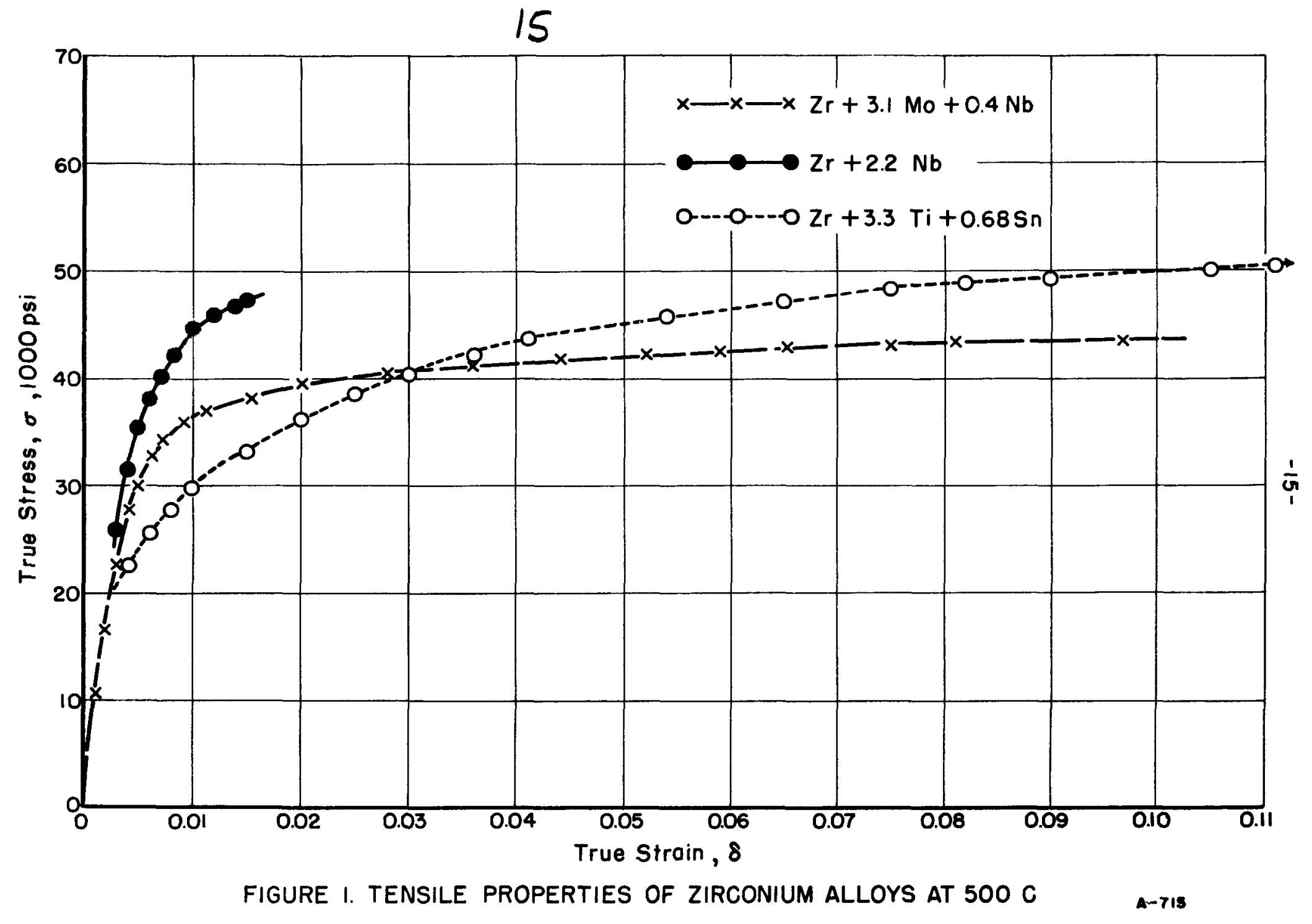




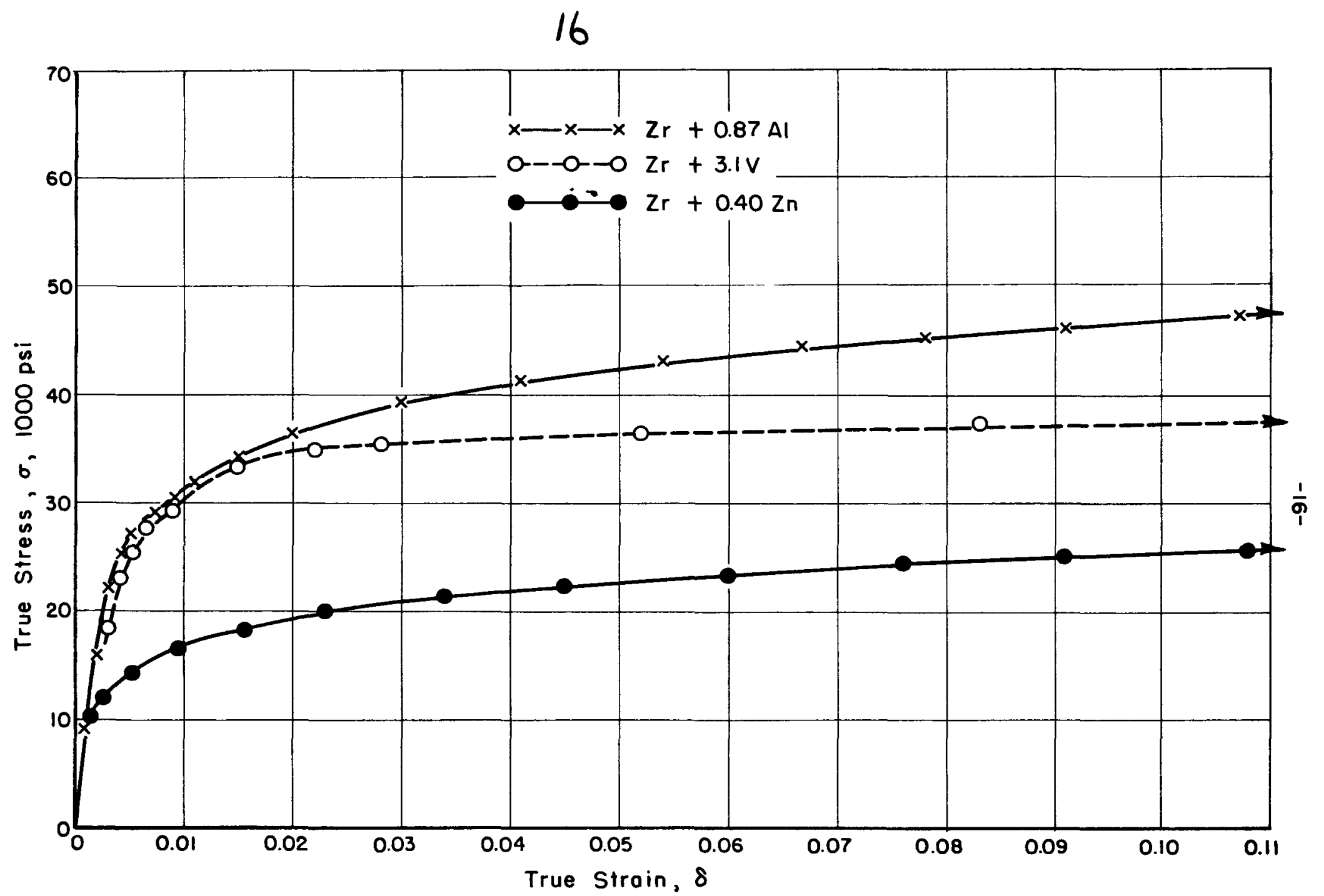

FIGURE 2. TENSILE PROPERTIES OF ZIRCONIUM ALLOYS AT $500 \mathrm{C}$ 
17

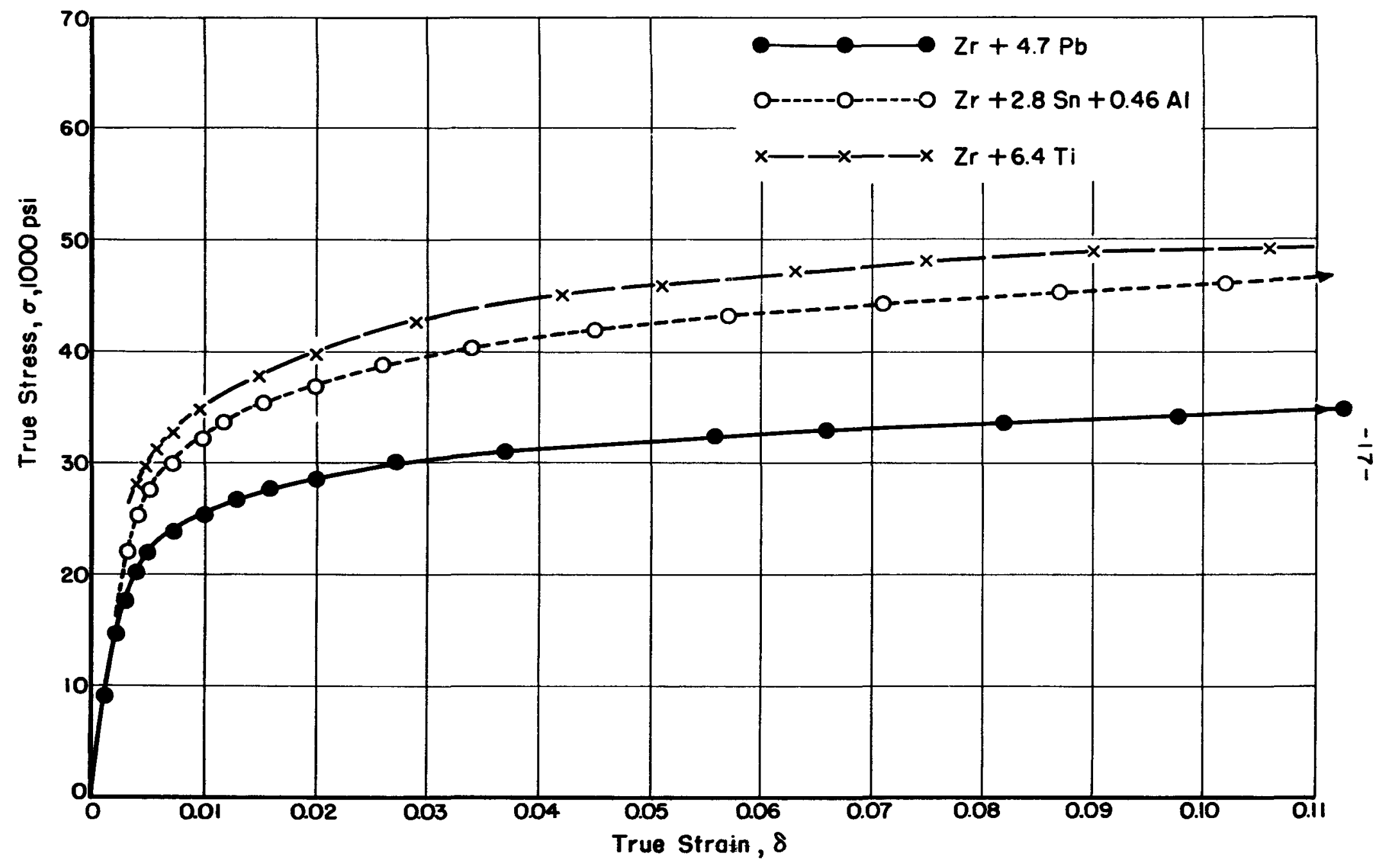

FIGURE 3. TENSILE PROPERTIES OF ZIRCONIUM ALLOYS AT $500 \mathrm{C} \quad A-715$ 


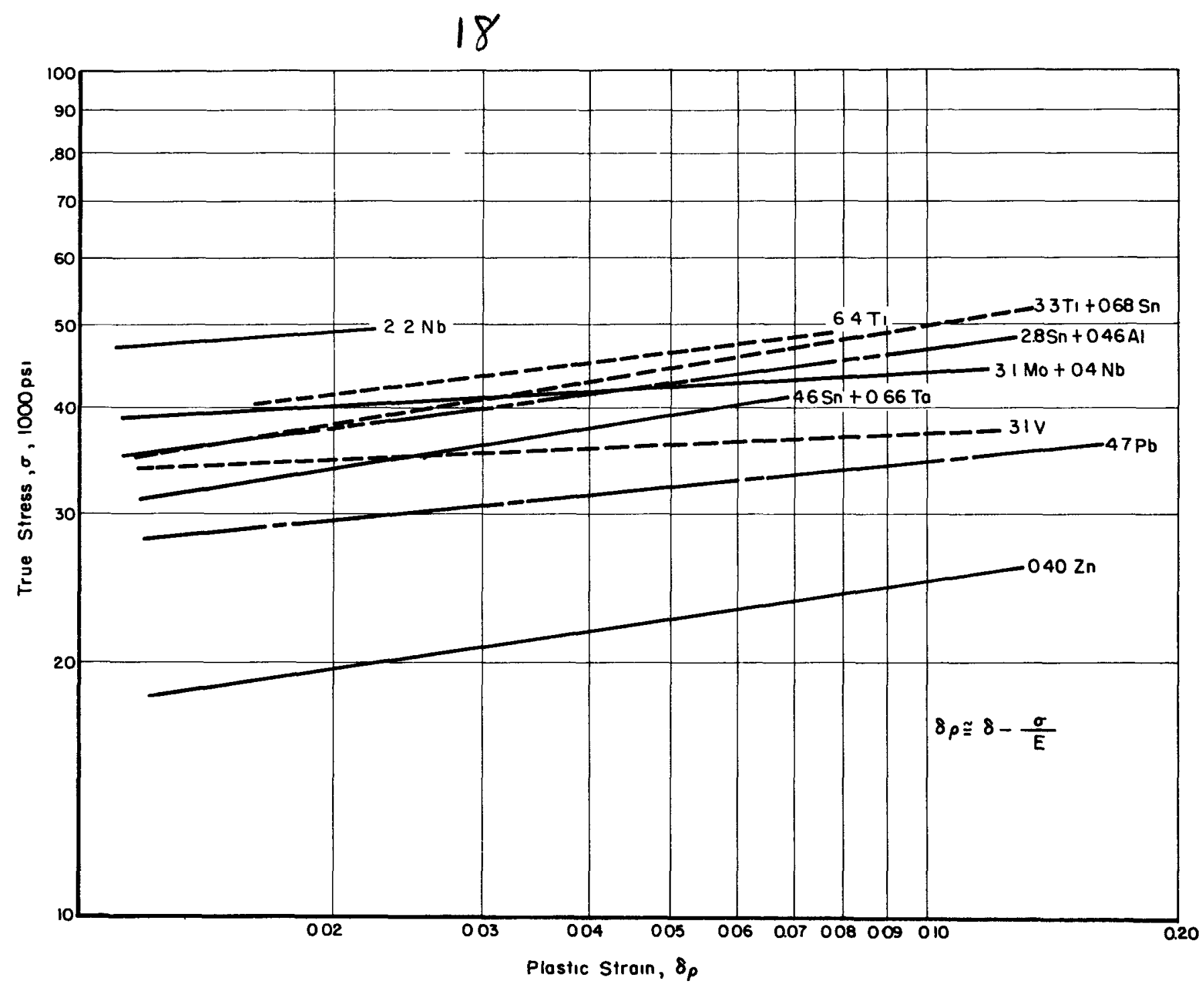

FIGURE 4. PLASTIC-STRAIN-HARDENING CURVES FOR ZIRCONIUM ALLOYS AT $500 \mathrm{C}$ 
TABLE 4. PROPERTIES OF ZIRCONIUM ALLOYS COMPARED WITH PROPERTIES OF STAINLESS STEEL AT $500 \mathrm{C}$

\begin{tabular}{|c|c|c|c|}
\hline $\begin{array}{c}\text { Zirconium Alloys, } \\
\text { weight per cent } \\
\text { (as analyzed } * \text { ) }\end{array}$ & $\begin{array}{c}\text { Thermal-Neutron- } \\
\text { Capture Cross Section, } \\
\text { barns/atom }\end{array}$ & $\begin{array}{l}\text { Cross- } \\
\text { Section } \\
\text { Ratio }\end{array}$ & $\begin{array}{l}\text { Yield- } \\
\text { Strength } \\
\text { Ratio }\end{array}$ \\
\hline $3.1 \mathrm{Mo}+\mathrm{C} .4 \mathrm{Nb}$ & 0.27 & 0.094 & 1.03 \\
\hline $2.2 \mathrm{Nb}$ & 0.22 & 0.077 & 1.13 \\
\hline $0.003 \mathrm{Mg}$ & 0.20 & 0.070 & 0.52 \\
\hline $0.003 \mathrm{Mg}^{\prime}$ & 0.20 & 0.070 & 0.29 \\
\hline $3.3 \mathrm{Ti}+0.68 \mathrm{Sn}$ & 0.54 & 0.189 & 0.77 \\
\hline $0.38 \mathrm{Al}$ & 0.20 & 0.070 & 0.58 \\
\hline $0.87 \mathrm{Al}$ & 0.20 & 0.070 & 0.81 \\
\hline $0.44 \mathrm{~W}$ & 0.24 & 0.084 & 0.54 \\
\hline $3.1 \mathrm{~V}$ & 0.45 & 0.157 & 0.89 \\
\hline $0.40 \mathrm{Zn}$ & 0.21 & 0.073 & 0.39 \\
\hline 4. $7 \mathrm{~Pb}$ & 0.20 & 0.070 & 0.68 \\
\hline $2.8 \mathrm{Sn}+0.46 \mathrm{Al}$ & 0.21 & 0.073 & 0.95 \\
\hline $4.6 \mathrm{Sn}+0.66 \mathrm{Ta}$ & 0.28 & 0.098 & 0.83 \\
\hline 6. $4 \mathrm{Ti}$ & 0.86 & 0.300 & 0.96 \\
\hline
\end{tabular}

* Carbon analyses are shown in Table 1. 
The problem is to obtain the desired strength when the amount of alloying element is limited by the thermal-neutron-capture cross section of some elements and when ductility is limited by the limited solid solubility of other elements.

The results shown in Table 4 indicate, therefore, that alloys may be picked from this group for creep testing on the basis of their tensile properties alone. These results point to the 2.2 per cent niobium alloy, the 3.3 per cent titanium plus tin alloy, the 0.87 per cent aluminum alloy, the 3.1 per cent vanadium alloy, the 2.8 per cent tin plus aluminum alloy, and the 6.4 per cent titanium alloy. Alloys of approximately these compositions will be prepared and examined for creep resistance.

\section{Microstructure}

Sections of the alloys as annealed for 3 hours at $700 \mathrm{C}$ were mounted in bakelite, polished by hand to $4 / 0$ paper, and etched with 2 per cent ammonium bifluoride- 2 per cent ammonium persulfate solution.

Carbides were present in all alloys in the form of relatively large eliptical or spherical particles.

No second phase, other than the carbide, was detected in the 2.2 per cent niobium alloy, the magnesium alloys, the 3.3 per cent titanium plus tin alloy, the 0.40 per cent zinc alloy, the 4.7 per cent lead alloy, nor the 6.4 per cent titanium alloy.

A trace of a second phase was detected in the 3.1 per cent molybdenum plus niobium alloy, in the 0.38 per cent aluminum alloy, and in the 2.8 per cent tin plus aluminum alloy.

Appreciable amounts of second phase were visible in the 0.87 per cent aluminum alloy, the 0.44 per cent tungsten alloy, the 3.1 per cent vanadium. alloy, and the 4.6 per cent tin plus tantalum alloy.

\section{Corrosion Data}

Small pieces of each alloy were corroded in a stainless steel retort in an atmosphere saturated with water vapor at $360 \mathrm{C}$.

At the end of 100 hours, the stronger magnesium alloy, the 3.3 per cent titanium plus tin alloy, the aluminum alloys, the vanadium alloy, the 
zinc alloy, the lead alloy, the 2.8 per cent tin plus aluminum alloy, and the titanium alloy were badly oxidized and had to be removed from the retort.

At the end of 350 hours, the 0.44 per cent tungsten alloy was oxidizec. and had to be removed from the retort; the 3.1 per cent molybdenum plus niobium alloy, the 2.2 per cent niobium alloy, and the 4.6 per cent tin plus tantalum alloy were noticeably oxidized. Only the weaker magnesium alloy, which is presumed to be relatively pure zirconium, satisfactorily survived 350 hours in the retort.

It is apparent from the above results that aluminum and tantalum adversely affect the corrosion resistance of zirconium-tin alloys. It may be that molybdenum and niobium have a less harmful effect upon the corrosion resistance of zirconium than most other elements, however, they do not seem to have the same beneficial effect as tin.

\section{Transformation Temperatures}

The transformation temperatures of some of the binary alloys in this group were determined by means of differential thermal analysis. A nickel sample was used as a reference body, and the temperature difference between this reference body and a 30-gram sample of each zirconium alloy was measured. Chromel-Alumel thermocouples and a $0.035 \mathrm{microamp} / \mathrm{mm}$ galvanometer were used to record the temperature variations between the reference body and the alloy. The alloy was heated and cooled at a rate - of approximately $4 \mathrm{C}$ per minute. The accuracy of these determinations is $\pm 15 \mathrm{C}$.

The data from this investigation are shown in Table 5. It is apparent that niobium, aluminum, tungsten, vanadium, zinc, and lead lower the transformation temperature of zirconium. The slight elevation of the transformation temperature indicated for the 0.003 per cent magnesium alloy is probably caused by other impurities such as carbon, or possibly nitrogen. 
TABLE 5. TRANSFORMATION TEMPERATURES OF ZIRCONIUM ALLOYS

\begin{tabular}{|c|c|c|c|c|}
\hline \multirow{3}{*}{$\begin{array}{c}\text { Zirconium Alloys, } \\
\text { weight per cent } \\
\text { (as analyzed*) } \\
\end{array}$} & \multicolumn{4}{|c|}{ Transformation Range } \\
\hline & \multicolumn{2}{|c|}{ On Heating } & \multicolumn{2}{|c|}{ On Cooling } \\
\hline & Begin, $C$ & End, C & Begin, $\mathrm{C}$ & End, $C$ \\
\hline $2.2 \mathrm{Nb}$ & 785 & 882 & 810 & 710 \\
\hline $0.003 \mathrm{Mg}$ & 871 & 949 & - & - \\
\hline $0.38 \mathrm{Al}$ & 754 & 791 & 771 & 721 \\
\hline $0.44 \mathrm{~W}$ & 779 & 846 & 832 & 788 \\
\hline $3.1 \mathrm{~V}$ & 749 & 779 & 774 & 724 \\
\hline $0.40 \mathrm{Zn}$ & 804 & 846 & 846 & 813 \\
\hline 4. $7 \mathrm{~Pb}$ & 821 & 868 & 882 & 832 \\
\hline
\end{tabular}

* Carbon analyses are shown in Table 1.

Heat-Treating Data

A section of each alloy as cold rolled and annealed in the form of sheet was further treated for three hours at $700 \mathrm{C}$. The specimens were cooled to $650 \mathrm{C}$ over a period of about 15 minutes and then furnace cooled to room temperature. The Rockwell hardnesses of the alloys in this condition were taken to be their fully annealed hardnesses. These samples were reheated to $700 \mathrm{C}$ and quenched in water. The hardnesses of the quenched specimens were found to be very nearly the same as the annealed specimens and no significance was attached to this phenomenon.

The same samples were reheated to $950 \mathrm{C}$ and quenched in water. They were then heated, for two hours at $540 \mathrm{C}$ and some of them for an additional periòd of four hours at $540 \mathrm{C}$. Rockwell hardnesses of the specimen were obtained after each treatment. The results of these tests are shown in Table 6. Some hardening is evident in the 0.44 per cent tungsten, the 3.1 per cent vanadium, and the 0.40 per cent zinc samples as quenched from above the transformation temperature.

Pure zirconium shows a hardening when quenched from above the transformation temperature, and this hardening is attributed to straining resulting from the martensite-type reaction found in this material. However, zirconium alloys often do not show hardening when quenched from above their transformation temperature, probably because of the sluggishness of the martensite reaction in these alloys. The results listed in 
Table 6 suggest that the martensite reaction is more vigorous in zirconium alloys of tungsten, vanadium, and zinc.

TABLE 6. HEAT-TREATING DATA

\begin{tabular}{|c|c|c|c|c|c|}
\hline \multirow[b]{2}{*}{$\begin{array}{c}\text { Zirconium Alloys, } \\
\text { weight per cent } \\
\text { (as analyzed*) }\end{array}$} & \multicolumn{5}{|c|}{ Rockwell A Hardnesses } \\
\hline & $\begin{array}{c}\text { Annealed at } \\
700 \mathrm{C} \\
\text { for } \\
3 \text { hours } \\
\end{array}$ & $\begin{array}{l}\text { Quenched } \\
\text { in Water } \\
\text { from } \\
700 \mathrm{C} \\
\end{array}$ & $\begin{array}{c}\text { Quenched } \\
\text { in Water } \\
\text { from } \\
950 \mathrm{C} \\
\end{array}$ & $\begin{array}{c}\text { Aged } \\
2 \text { Hours } \\
\text { at } \\
540 \mathrm{C} \\
\end{array}$ & $\begin{array}{c}\text { Aged } \\
6 \text { Hours } \\
\text { at } \\
540 \mathrm{C}\end{array}$ \\
\hline $3.1 \mathrm{Mo}+0.4 \mathrm{Nb}$ & 65 & 65 & 66 & 67 & - \\
\hline $2.2 \mathrm{Nb}$ & 69 & 65 & 65 & 68 & - \\
\hline $0.003 \mathrm{Mg}$ & 65 & 66 & 59 & 62 & - \\
\hline $0.003 \mathrm{Mg}^{\prime}$ & 45 & 49 & 47 & 48 & - \\
\hline $3.3 \mathrm{Ti}+0.68 \mathrm{Sn}$ & 57 & 60 & 59 & 58 & - \\
\hline $0.38 \mathrm{Al}$ & 54 & 54 & 58 & 57 & 58 \\
\hline $0.87 \mathrm{Al}$ & 53 & 54 & 56 & 57 & 57 \\
\hline $0.44 \mathrm{~W}$ & 48 & 49 & 60 & 62 & 62 \\
\hline $3.1 \mathrm{~V}$ & 54 & 54 & 74 & 63 & 63 \\
\hline $0.40 \mathrm{Zn}$ & 43 & 44 & 54 & 53 & 53 \\
\hline 4. $7 \mathrm{~Pb}$ & 54 & 54 & 55 & 57 & 55 \\
\hline $2.8 \mathrm{Sn}+0.46 \mathrm{Al}$ & 55 & 55 & 57 & 58 & 57 \\
\hline $4.6 \mathrm{Sn}+0.66 \mathrm{Ta}$ & 56 & 56 & 57 & 58 & 58 \\
\hline $6.4 \mathrm{Ti}$ & 58 & 60 & 65 & 61 & 60 \\
\hline
\end{tabular}

* Carbon analyses are shown in Table 1.

\section{Hot-Hardness Data}

Diamond pyramid hardnesses of the alloys were obtained at elevated temperatures by means of a vacuum hot-hardness machine. This machine consists of a stationary diamond indenter mounted over a hydraulically operated stage, both of which are heated by open wire heating coils and are contained in an evacuated chamber. A thermocouple mounted in the stage records the temperature of the specimen. Four indentations were made at room temperature, $204 \mathrm{C}, 316 \mathrm{C}, 427 \mathrm{C}, 538 \mathrm{C}$, and $649 \mathrm{C}$. Three indentations were made at $704 \mathrm{C}, 760 \mathrm{C}, 816 \mathrm{C}$, and $871 \mathrm{C}$. The diamond pyramid hardness numbers obtained from these indentations were averaged and plotted versus temperature. A smooth curve was drawn through these points; values selected from these curves appear in Table 7. 
TABLE 7. HOT-HARDNESS DATA

\begin{tabular}{|c|c|c|c|c|}
\hline \multirow{2}{*}{$\begin{array}{c}\text { Zirconium Alloys, } \\
\text { weight per cent } \\
\text { (As Analyzed*) }\end{array}$} & \multicolumn{4}{|c|}{ Diamond Pyramid Hardness Number } \\
\hline & $\begin{array}{c}\text { Room } \\
\text { Temperature } \\
\end{array}$ & $300 \mathrm{C}$ & $500 \mathrm{C}$ & $700 \mathrm{C}$ \\
\hline $3.1 \mathrm{Mo}+0.4 \mathrm{Nb}$ & 341 & 158 & 97 & 32 \\
\hline $2.2 \mathrm{Nb}$ & 258 & 159 & 89 & 25 \\
\hline $3.3 \mathrm{Ti}+0.68 \mathrm{Sn}$ & 235 & 154 & 99 & 44 \\
\hline $0.87 \mathrm{Al}$ & 228 & 151 & 108 & 50 \\
\hline $0.44 \mathrm{~W}$ & 172 & 110 & 70 & 29 \\
\hline $3.1 \mathrm{~V}$ & 168 & 120 & 88 & 44 \\
\hline 4. $7 \mathrm{~Pb}$ & 188 & 105 & 57 & 22 \\
\hline $2.8 \mathrm{Sn}+0.46 \mathrm{Al}$ & 215 & 167 & 124 & 56 \\
\hline $4.6 \mathrm{Sn}+0.66 \mathrm{Ta}$ & 222 & 144 & 98 & 48 \\
\hline $6.4 \mathrm{Ti}$ & 209 & 151 & 102 & 43 \\
\hline
\end{tabular}

* Carion analyses are shown in Table 1.

These data agree in a very general way with the tensile data shown in Table 3, and are particularly interesting because they indicate that titanium, tin, aluminum, and vanadium are especially effective in maintaining the high-temperature hardness of zirconium.

\section{CONCLUSIONS}

1. Zirconium alloys of aluminum, lead, molybdenum, niobium, tantalum*, tin, titanium, and vanadium have been successfully produced with 0.2 per cent yield strengths at $500 \mathrm{C}$ of 20,000 psi or more.

2. Zirconium alloys containing 4.7 per cent lead, 0.82 per cent molybdenum*, 2. 2 per cent niobium, 1.35 per cent tin*, 6.4 per cent tantalum*, 49 per cent titanium*, 0.40 per cent zinc, and 3.3 per cent titanium plus 0.68 per cent tin are all solid-solution-type alloys.

3. Zirconium alloys containing 0.38 per cent aluminum, 0.44 per cent tungsten, and 3.1 per cent vanadium are two-phase-type alloys.

- Conclusion based on work reported in BMI-79.

GPO $822904-2$ 
4. Molybdenum and niobium seem to have a less harmful effect upon the corrosion resistance of zirconium than most other elements (excepting tin).

5. Aluminum, lead, molybdenum*, niobium, tantalum*, tungsten, titanium*, vanadium, and zinc lower the transformation temperature of zirconium; carbon* and nitrogen* raise it appreciably; and 1.35 per cent tin* seems to have little effect upon the transformation temperature of zirconium.

6. The 0.44 per cent tungsten alloy, the 3.1 per cent vanadium alloy, and the 0.40 per cent zinc alloy can be hardened slightly by quenching from above the transformation temperature.

7. Hot-hardness data indicate that aluminum, tin, titanium, and vanadium are especially effective in maintaining the high-temperature strength of zirconium.

8. Vanadium seems to decrease the oxidation resistance of zirconium at $1000 \mathrm{C}$ less than some of the other alloying elements. 


$$
1-25
$$

! 